\title{
OS RELATOS DE VIAGEM EM FOCO: GOA AND THE BLUE MOUNTAINS OR SIX MONTHS OF SICK LEAVE DE SIR RICHARD FRANCIS BURTON'
}

\author{
Cielo Griselda Festino \\ Doutoranda pelo Depto. de Letras Modernas-FFLCH/USP
}

\begin{abstract}
Resumo
O presente artigo traz uma leitura do relato de viagem Goa and the Blue Mountains or Six Months of Sick Leave (1851) de Sir Rirchard F. Burton discutindo como o autor constrói a si mesmo, enquanto narrador, assim como a sua textualização do Oriente colonial, neste caso a Índia, em um enredo reconhecível para o seu público europeu. Questões de forma e conteúdo serão consideradas, já que as estratégias ficcionais utilizadas revelam a construção ideológica do colonizador.
\end{abstract}

\section{Abstract}

This paper aims at a reading of Sir Richard Francis Burton's Goa and the Blue Mountains or Six Months of Sick Leave (1851) considering how from an imperial perspective, he both constructs himself as narrator in his text and also semioticizes the Orient, in this particular case India, in a way that is meaningful to his audience back home. We will discuss not only the tale being told but also the way it is emplotted since we understand that the fictive strategies employed postulate the ideological construction of the colonizer.

\section{Pallavras-Chave}

Relatos de viagem - Estratégias ficcionais - Ideologia - Colonizador - Colonizado

\section{Keywords}

Travel writing - Fictive Strategies - Ideology - Colonizer - Colonized

\footnotetext{
${ }^{1}$ Escrito a partir do curso de pós-graduação "Viagens e Viajantes do Ocidente moderno: A literatura de viagem dos séculos XVIII, XIX eXX" ministrado pela Profa. Dra. Maria Helena P.T. Machado, DHFFLCH/USP $-2^{\circ}$ sem./2000.
} 


\section{Introdução}

S egundo Menezes de Souza (1996a: 6), "A literatura colonizadora cogita o mundo colonial como um confronto de raças, línguas, valores sócio-culturais e meios de produção e tenta 'resolver' essas contradições ideológicas procurando emprestarlhes uma coerência aparente", a do colonizador.

Tentaremos desconstruir e resignificar, justamente essa coerência, por meio da presente leitura do relato de viagem Goa and the Blue Mountains or Six Months of Sick Leave ${ }^{2}$ (1851), primeiro relato do famoso viajante e escritor inglês do século XIX Sir Richard Francis Burton ${ }^{3}$. Nessa viagem através da Índia colonial inglesa e portuguesa, Burton sai de Bombaim e segue o roteiro percorrido por Vasco da Gama em 1499: Goa, Calicut, Malabar, chegando até Ootacamund, onde passa sua licença por convalescência em um centro inglês de recuperação para a saúde. Ao tempo que avança, Burton observa e com seu olhar cataloga lugares e pessoas, revelando o que constitui o locus enunciativo do viajante do século XIX no Oriente.

Seguindo o pensamento de Mary L. Pratt (1992) na presente leitura do relato consideraremos como Burton 'produz' esse mundo colonial indiano, através do seu olhar imperialista. Levamos em conta tanto questões de forma quanto de ideologia, já que entendemos o discurso de forma geral e o colonial em particular, como um sistema de significações no qual o sentido não se apresenta somente nos fatos narrados, mas também na maneira como são construídos. Entendemos assim que as características retóricas do texto de Burton são altamente funcionais, uma vez que revelam a construção ideológica do colonizador.

Com esse propósito, é a nossa intenção interpretar como no texto Burton constrói a si mesmo enquanto narrador e a maneira pela qual textualiza o Oriente colonial

\footnotetext{
2 'Goa e as montanhas azuis ou seis mêses de licença por convalescença'.

${ }^{3}$ Sir Richard Francis Burton é autor de um grande números de relatos de viagem a África, Asia e América entre as quais se encontram The Highlands of Brazil (1869), The Captivity of Hans Staden of Hesse in A.D. 1547-1555. Among the Wild Tribes of Eastern Brazil (1874).
} 
em um enredo reconhecível e aceitável ao público europeu. Num segundo momento, faremos uma breve recapitulação daqueles temas que Burton escolhe, durante o seu roteiro pela Índia, por considerá-los de interesse para um público metropolitano, apontando a 'violência da escrita', quando, através da mesma, essas culturas confrontam-se em uma relação claramente assimétrica.

\section{A viagem e o texto}

Muitos dos textos tradicionalmente lidos meramente como representações do Ocidente acerca do mundo colonial - romances, estórias, crônicas, relatos de viagem, diários de viagem, etc. - são agora considerados como exemplos da maneira pela qual têm servido ao processo histórico de colonização. Dessa perspectiva, eles são estudados como "construções coloniais de significado" (Pratt 1992:27), tentando entender como o escritor ocidental representava e se apropriava, de uma forma 'coerente' para o ocidente, daquelas realidades incompreensíveis com as quais se confrontava no mundo não ocidental (Spurr 1993:3).

O relato de viagem é um bom um exemplo dessa retórica expansionista dos séculos XVII, XVIII e XIX, uma vez que, longe de ser uma narrativa inocente, é uma das formas de conquista em que o viajante-cum-escritor, a partir de sua 'própria estrutura conceptual' (Pratt 1992:89), integra os novos territórios e, por extensão, o colonizado, ao seu mundo, projetando geográfica e textualmente um universo de saberes e poderes sobre eles. Pratt explica que "tais práticas de estabelecimento de significado codificam e legitimam as aspirações de expansão econômica do império" (1992:28).

No século XIX, época do apogeu imperialista, o Oriente (assim como a América e a África) foi um dos destinos mais comuns para esses peregrinos, que eram ao mesmo tempo cientistas, soldados, aventureiros, comerciantes, Orientalistas. Suas narrativas, por sua vez, como explica Edward Said em Orientalismo (1978), têm muito a ver com a natureza do peregrino, sua maneira de escrever e intencionalidade da viagem. Said acrescenta que "cada trabalho importante pertencente a um Orientalismo genuíno, embora nem sempre acadêmico, toma a sua forma, estilo e intenção da idéia de uma peregrinação" (1978:169). 
Richard F. Burton é um desses peregrinos. Aventureiro, soldado e Orientalista, não só viajou ao Oriente, mas também lá residiu, como membro da Companhia das Índias Orientais. Proficiente estudioso de línguas orientais e tradutor de obras como As Mil e Uma Noites, Kama Sutra e Os Lusíadas, a textualidade dos seus relatos de viagem reflete, nas palavras de Edward Said ao definir os Orientalistas, "uma certa liberdade na relação com o outro, na sua maneira de dar forma ao Grande Mistério Asiático" (1978:44), que resulta do fato de ser ciente de pertencer à uma cultura considerada mais forte.

A liberdade em sua relação com o Outro, que se manifesta na textura de Goa and the Blue Mountains, está também relacionada com o fato de que, na Índia, viajava por uma das maiores colônias do império britânico. Como, uma vez mais acentua Said, para os ingleses, “o Oriente era a Índia, e esta uma possessão britânica; cruzar o Oriente Médio significava estar na rota de uma das suas maiores colônias” (1978:169).

Durante a viagem - em que sai de território inglês, entra em área portuguesa, para depois retornar à colônia inglesa - Burton demonstra estar ciente do fato de a Inglaterra ser soberana na Índia, através da sua permanente comparação crítica, implícita e explícita, em relação aos colonizadores portugueses, que "há muito tempo já não eram rivais ativos para os ingleses no Oriente" (Rice 1990:47), e aos "nativos" da Índia, fato que constantemente permeia o texto.

Os motivos dessa viagem são pessoais e não científicos e, de alguma maneira, estão resumidos no título da narrativa. Um deles seria recuperar-se totalmente do cólera, doença que contraiu durante uma epidemia em Karachi, no balneário e centro de convalescência para oficiais britânicos com suas famílias em Ootacamund (Rice 1990:152). Ao mesmo tempo, demonstrava-se interessado pelo poeta português Luis Vaz de Camões, que tinha passado algum tempo em Goa, onde escreveu grande parte do mais famoso poema de língua portuguesa, Os Lusíadas. Segundo Rice, "a doença pode ter sido uma desculpa para Burton sair de Sind e dar um pulo até a colônia portuguesa de Goa, para investigar Camões in situ" (1990:152), uma vez que os interesses intelectuais eram uma de suas mais importantes motivações. 


\section{Aspectos Formais}

Em A retórica do império, David Spurr aponta que "narrar começa com olhar" (1993:13). Aquilo que o viajante vê está condicionado por sua própria estrutura ideológica. Para contar a sua viagem, Burton constrói-se no texto enquanto narrador, através da primeira pessoa do plural ' $w e$ ', o que mostra uma das convenções deste tipo de literatura no seu desejo de despersonalizar aquilo que está sendo narrado e assim conferir-lhe maior verosimilhança. A sua presença no texto, contudo, é marcante, uma vez que reiteradamente interrompe seu relato, tanto para abertamente se dirigir ao leitor como para opinar sobre o que contempla. Isso o aproxima do leitor colocando a sua narrativa mais na área do relato livre do que na do texto erudito, como é o caso de Orientalismo. Em algumas ocasiões, com a clara intenção de acomodar suas aventuras sexuais à sua audiência Vitoriana, Burton constrói-se também como narrador na terceira pessoa, atrás da figura de um "jovem oficial inglês".

Isto demostra que, enquanto tradutor e intérprete de uma cultura alheia, o escritor, ao sistematizar suas impressões no texto, está ciente da audiência à qual sua narrativa é dirigida, adaptando seu discurso a essa realidade. No caso de Burton, ao narrar as suas viagens por Goa e outras cidades, ele conhece a complexidade de sua platéia Vitoriana na Inglaterra. Ao tratar dessa característica dos relatos do explorador/ escritor, Mary L. Pratt explica "como o relato de viagens e exploração" produziu "o resto do mundo para leitores europeus em momentos particulares da trajetória expansionista européia" (1992:28).

No texto de Burton, o leitor aparece muitas vezes representado por meio das variantes do famoso "Dear Reader", tão familiar aos romances do século XIX, época na qual Burton estava escrevendo. Assim, repetidamente, o texto faz apelações ao leitor: "Yes, dear madam or gentleman" (8); "Purely European readers" (270); "Imaginative reader" (368).

Em $A$ arte da ficção, David Lodge explica que a presença do leitor no relato é uma estratégia ficcional que objetiva complicar as respostas do "leitor real", à margem do texto (1992:81). Acreditamos que Burton adota esta estratégia, muitas vezes de forma irônica, para implicitamente criticar a visão romantizada do Oriente, 
um lugar comum na literatura ocidental do século XIX, muito procurada pelos leitores. Por sua vez, ele também ironiza a maneira de escrever de alguns autores, a quem chama de "gentlemen tourists","poetical authors" ou "lady prosers" (5) , e a sua versão do Oriente na literatura em geral e os relatos de viagem em particular.

Já desde o primeiro capítulo, intitulado 'The Voyage', Goa and the Blue Mountains é uma sátira das românticas lendas do mar que, segundo Tony Tanner (1995), tanto livram o homem do land-imprisonment - a prisão que a terra firme representa para o homem do mar- como apresentam o navio como um local de beleza, mistério e sonho:

What a glad moment it is, to be sure, when the sick and seedy, the tired and testy invalid from pestiferous Scinde or pestilential Guzerat, 'leaves all behind him' and scrambles over the sides of his Pattimar.

His what?

$\mathrm{Ah}$ ! We forget. The gondola and barque are household words in your English ears, the budgerow is beginning to own an old familiar sound, but you are right- the 'Pattimar' requires a definition (1) $)^{5}$.

O clichê sentimental "leave all behind" está em contraponto com a adjetivação negativa usada nesta passagem - "sick” (doente), "seedy” (miserável, degradado), “testy” (irritável) e os transparentes "pestiferous" e "pestilential” - a qual vem demostrar que a idealização típica do Romantismo, a que Burton faz alusão em outras passagens de seu texto, está totalmente fora da narrativa. Ao mesmo tempo, o verbo "scramble" (engatinhar) afirma essa idéia ao completar uma imagem que tem mais conotações de grotesco do que de romântico, o que implicitamente contesta outros textos que mostram partidas de uma maneira que sugere a alegria da viagem e a dor

\footnotetext{
4 'os turistas cavaleiros, os autores poetas e as damas escritoras'.

5 'Que feliz momento quando o doente e o miserável, o cansado e o inválido da pestifera Scinde ou a fedorenta Guzeral ‘deixa tudo para trás’ e engatinha-se no Pattimar. O que? Ah! Tínhamos esquecido! A gôndola e a barca são palavras comuns para os seus ouvidos ingleses, o budgerow começa a ter um som familiar, mas, vocês estão certos, o 'Pattimar' pede uma definição'.
} 
das despedidas. A situação é ainda mais carregada de significados se considerarmos que quem está doente e arrasta-se ao pattimar é, justamente, o próprio Burton.

Da mesma maneira, ao descrever o pattimar, o autor ironiza os homens do mar e suas lendas oferecendo "a pure landman's description of the article in question" (1-2) ${ }^{6}$, ou seja, o navio. Burton substitui o jargão quase ininteligível da navegação por um vocabulário mais simples, o que torna-se anátema para o marinheiro experiente, mas um verdadeiro alívio para o leitor não especializado. Burton descreve, de forma ironicamente didática, o pattimar para sua audiência: “De suite: you shall pourtray it from our description. Sketch a very long boat, very high behind, and very low before, composed of innumarable bits of wood tied together with coir...” (2).

Tony Tanner explica que uma outra característica desse tipo de relato é, justamente, apresentar "the men in the ship" e a relação entre os membros dessa comunidade onde as mulheres estão ausentes. Segundo ele, as emoções descritas geralmente são, coragem, resolução, resistência, e, além de tudo, o conhecimento e o amor pelo mar e a navegação. Burton, ao contrário, descreve os homens do pattimar a partir de uma perspectiva que mostra desde o principio o conflito no contexto colonial entre o local e o imperial e que nada sugere uma idealizada relação de camaradas.

Assim, ele narra que ainda na costa de Bombaim, o pattimar não saiu devido à ineficiência da tripulação: "Now the last 'nigger', in a manifest state of full inebriation, has rolled into, and the latest dun, in a fit of diabolical exasperation, has rolled out of the pattimar" $(7)^{8}$. Da mesma forma, o capitão do navio, "the Tindal", não é muito melhor que sua tripulação: "Observe if you please, the Tindal swears by all the skulls of the god Shiva's necklace, that the wind is foul - the tide don't serve- his crew is absent - and the water not yet on board" (7) ${ }^{9}$.

\footnotetext{
6 'a descrição de um leigo do artigo em questão'.

7 'Nossa descrição vai ajudá-los a retratar o navio. Desenhe um bote comprido, alto atrás e baixo na frente, composto de inumeráveis peças de madeira unidas por uma corda'.

8 'O último negro claramente embebedado subiu ao 'pattimar' e o último mulato, num diabólico estado de exasperação, desceu do pattimar'.

9 'Pode-se observar que o capitão maldisse por todas as caveiras do colar do deus Shiva, o vento é contrário, a maré não ajuda, a tripulação está ausente, e a água não chega a bordo’.
} 
Essa passagem vem demostrar que o texto de Burton é, como sugerido anteriormente, uma desconstrução da visão romantizada das viagens ao Oriente ao tempo que marca explicitamente o lugar de autoridade do homem branco no Oriente e o seu controle sobre o nativo. Dirigindo-se ao leitor diz: "just remark how one small touch of our magic slipper upon the region of the head, and the use of that little phrase 'Suar ka Sala' (Anglicé: 'O brother-in-law of a hog!) has made the wind fair, the tide serve, the crew muster and the water pots abound in water"' (7-8) ${ }^{10}$. Tudo isto faz com que Burton seja visto pelo Tindal como um "Assal Sahib - a real gentleman" (8) enquanto que a narrativa parece inferir que esta relação pouco amistosa, quase de violência, e a atitude debochada por parte do Nativo, é o verdadeiro Oriente.

Depois dessa detalhada e quase grotesca descrição de todos os inconvenientes e peculiaridades tanto do pattimar como de seus tripulantes, finalmente utiliza-se de parte das convenções desse tipo de relato e admite o prazer da viagem: "So if you are human, your heart bounds, and whatever its habits of grumbling may be, your tongue involuntarily owns that it is a joyful moment when you scramble over the side of your pattimar" (4)

Então, Burton convida o leitor a, junto com ele, subir a bordo do pattimar. Demonstrando ao mesmo tempo que sua audiência está fora do mundo colonial que ele textualiza e que é através de seu relato que pode ter contato com essa realidade, Burton pede ao leitor, por meio do uso da segunda pessoa ' $y o u$ ', o que cria uma certa intimidade, que se coloque na sua perspectiva para se despedir de Bombaim, lugar da partida: "And now, [...] we will request you to walk up stairs with us, and sit upon the deck by our side, there to take one parting look at the boasted Bay of Bombay" (5) .

\footnotetext{
10 'Veja como um toque do nosso mágico chinelo, na região da cabeça, e o uso da frase 'Suar ka Sala' (anglicismo: 'cunhado de um porco') mudou o vento, às ondas ajudam, a tripulação controla o navio e a água abunda'.

11 "Se você é humano, seu coração bate, e a sua língua admite que é um momento feliz quando sobe ao pattimar'.

12 'Agora vamos pedir que você suba as escadas conosco e sente ao nosso lado para dar uma última olhada à soberba baia de Bombaim'.
} 
O adjetivo 'boasted' (presunçoso) implica que Burton, uma vez mais, não está disposto a confirmar a visão romantizada do Oriente:"We know that you are taking a trip with us to the land flowing with rupees and gold mohurs - growing an eternal crop of Nabobs and Nawwabs - showing a perpetual scene of beauty, pleasure and excitement" (6-7) ${ }^{13}$. Pelo contrário, sua intenção é desconstruí-la, através de uma outra visão, segundo ele, mais verdadeira, mas nem por isso menos subjetiva:

But we can't allow you to hand your rose-coloured specs over to us. We have long ago superseded our original 'greens' by a pair duly mounted with sober French grey glasses, and through these we look out upon the world as cheerily as our ophthalmic optics will permit us to do $(7)^{14}$.

Entendemos que nesta passagem Burton mostra seu próprio desejo de verdade, ao definir o lugar de autoridade do seu texto, uma vez que, embora não se trate de um relato erudito, mas o resultado livre de uma aventura pessoal, Burton residiu por vários anos no Oriente, o que lhe confere autoridade sobre o tema.

Said aponta que "a residência no Oriente implica experiência e testemunha pessoal" (1978:19). Ao tratar dos Orientalistas alemães, o autor de Orientalismo faz um comentário muito interessante que inclui Burton: "O Oriente alemão era quase exclusivamente textual ou clássico: era o tema de poemas líricos, fantasias e romances, mas nunca real, da maneira como Egito e Síria foram para Chateaubriand, Lane, Lamartine, Burton, Disraeli e Nerval" (1978:19).

Por esta perspectiva, Burton constrói a si e a tudo que contempla de uma maneira que implica um ponto de vista somente possível a verdadeiros residentes no Oriente, que realmente sabem do que estão falando. Ironicamente definindo seu leitor como

\footnotetext{
13 'Sabemos que você viaja conosco para a terra rica em rúpias e moedas de ouro - onde há uma eterna colheita de Nabobs e Nawabs - e a cena é de beleza, prazer e escitamento'.

14 'Não vamos aceitar os seus óculos cor-de-rosa. Faz muito tempo que temos deixado os nossos óculos 'verdes' e temos adotado um par de sobrias lentes francesas cor cinza. É através destas que enxergamos o mundo tão alegremente como a nossa ótica oftaalmica permitem' .
} 
grifo - termo usado na Índia e no Leste para se referir aos novatos no Oriente, especialmente aos brancos - Burton explica como ele, já experiente, entende o local, enfatizando a autoridade do seu texto: "But as you are a griff [...] we want to educate you in native peculiarities" (7) ${ }^{15}$. Burton propõe então contar a 'verdade', o que tem a ver com a relação entre viajante e viajado, aspecto da economia colonial que diz realmente entender ${ }^{16}$.

Porém, embora ironize os ingleses at home e a maneira pela qual imaginam o que existe além de suas fronteiras, é para eles que Burton escreve. Acreditamos que o modo pelo qual constrói os lugares que visita demonstra que o autor nunca esquece que sua audiência é branca, européia e preponderantemente inglesa e que é a esta sociedade que ele pertence. De forma que, para mostrar seu lugar entre eles, deixa claro que, embora in situ, está fora do meio que narra, compartilhando os mesmos códigos que seus leitores em seu país de origem. Burton reconhece o que Homi Bhabha chama de The English Book e é pensando nessa maneira de significar que ele escreve ${ }^{17}$. Esse fato fica explicitamente refletido, como sugerido anteriormente, ao também construir-se no texto, como narrador, por meio da figura do 'jovem oficial inglês'.

Em Orientalismo, Said faz alguns comentários sobre o viajante Lane que podem ser estendidos a Burton: "na maioria dos casos, o Oriente parece ter ofendido o decoro sexual. Tudo que tinha a ver com o Oriente implicava um tipo perigoso de sexo, ameaçava a higiêne e a decência doméstica" (1978:167). Por isso, ciente da maneira como a Inglaterra Vitoriana entendia o Oriente, Burton, que na sua estadia em Goa, fez muito mais que recolher dados sobre Camões, textualiza, em algumas partes do seu relato, suas andanças sexuais em terceira pessoa, como as de um “jovem oficial

\footnotetext{
15 'Mas como você é um grifo [...] queremos educá-lo nas peculiaridades nativas'.

${ }^{16}$ Segundo M. L. Pratt (1992) o termo ‘viajante' refere-se aos Ocidentais na Ásia, África e América enquanto 'viajados' representa os Nativos nesses lugares com os quais os primeiros interagem numa relação sempre ativa, embora o caráter passivo sugerido pela palavra 'viajados'.

${ }^{17}$ Em seu livro The Location of Culture (1994) Homi Bhabha refere-se a cultura inglesa que os súditos da coroa tentavam espargir por todo o seu império como 'the English book'.
} 
inglês", Desta maneira, o elemento transgressor da viagem, o sexual e erótico, é neutralizado na construção do texto que tenta seguir as normas estabelecidas pela sociedade européia.

Levando isso em conta, Burton narra uma de suas aventuras amorosas a partir da perspectiva de um colonizado, considerando a maneira em que o Nativo constrói o Sahib, o que vem a demostrar, em outro nível, o forte lugar de autoridade do colonizador, uma vez que acha que não só compreende a situação colonial, mas também compreende e pode reproduzir no texto como o Nativo a enxerga.

Assim, ao representar a maneira de narrar e falar de Salvador, o autor materializa o que Menezes de Souza aponta estar sempre presente no discurso em geral e o colonial em particular: "toda fala é, por natureza, intertextual e é habitada e constituída pela alteridade, pela fala do Outro, sendo que a voz, a expressão e o sotaque se fazem ouvir, em graus variados" (1996b:52). Mas, ao fazer isso, Burton ironicamente constrói uma alteridade colonial de acordo com o estereótipo criado pelo colonizador.

Atraído pelo proibido e no seu desejo de quebrar qualquer norma, Burton - "the heretic from Bombay" (62) ${ }^{19}$, como os católicos de Goa chamam aos protestantes - vai conhecer o convento de Santa Mônica na Velha Goa, onde a madre superiora enfaticamente negalhe a permissão para entrar e visitar os claustros onde moram as freiras.

Burton não entende o porquê dessa recusa até que Salvador, "after an hour's hesitation, falsification and prevarication" $(73)^{20}$, como é de se esperar de um nativo que só pode mentir e é “inconfiável e traiçoeiro" (Menezes 1996b: 63), perguntalhe se tinha se identificado como inglês. Surpreso, Burton pergunta o que é que seu país - a rivalidade entre Inglaterra e Portugal está sempre presente - tinha a ver com esta estória. Ao que Salvador responde que tem tudo a ver e tenta relatar a engraçada estória de um 'jovem oficial inglês'.

\footnotetext{
${ }^{18}$ Ao respeito, Edward Rice diz que 'os biógrafos aceitam como hipótese verdadeira' que o 'jovem oficial inglês' seja o mesmo Burton (1990:156).

19 'O herético de Bombaim'.

20 'Depois de uma hora de hesitar, falsificar e prevaricar'.
} 
Sendo Salvador um goês, um nativo, não poderia narrar corretamente uma estória sobre um inglês, pois não tem nem a autoridade nem a capacidade para isso. Burton, portanto encontra-se forçado a reconstruir a estória que Salvador, um nativo, só pode contar de maneira fragmentada, ordenando "the variety of distorted and disjointed fragments of an adventure which the labour of our ingenious cross questioning managed to put together in the following form" (73) ${ }^{21}$. Assim, apresentando-se em Salvador, Burton começa com o seu relato:

"About ten years ago", said Salvador, "I returned to Goa with my master Lieut. —, of the - Regt., a very clever gentleman, who knew everything. He could talk to each man of a multitude in his own language, and all of them would appear equally surprised by, and delighted with him' (73) ${ }^{22}$.

Burton coloca-se no texto a partir da perspectiva de Salvador, como uma pessoa de muito saber, ressaltando sua conhecida habilidade lingüística e o fato de que podia passar por um Nativo ${ }^{23}$. Ciente disso, em um momento do relato, quando com a ajuda de um afegão quer entrar no convento para raptar a moça, Burton faz Salvador dizer: "My master's face - as usual when he went upon such expeditions-was blackened, and with all respect, speaking in your presence, I never saw an English gentleman look more like a Mussulman thief!" $(82)^{24}$.

\footnotetext{
21 'Os fragmentos distorcidos e desconjuntados de uma aventura a qual só faz sentido depois de nossas geniais perguntas'.

22 'A cerca de dez anos, diz Salvador, 'retornei a Goa com o meu Senhor o Teniente - -, do Regimento - , um cavalhero muito inteligente que sabia de tudo. Podia falar muitas línguas e todos se surpreendiam e encantavam com ele'.

${ }^{23}$ Na sua biografia, Edward Rice conta como Burton estava sempre se aperfeiçoando no uso de línguas para algum serviço político. Além disso, seus hábitos domésticos eram árabes ou persas. Usava o alto da cabeça raspado, os cabelos compridos, a pele escura, $k o h l$ nos olhos e roupas locais. Em uma ocasião, vestido como andarilho persa, enganara até mesmo seu munshi (1990:162).

24 'O rosto de meu Senhor - como sempre que saía em tais expedições - estava pintado de negro e, com todo respeito, falando na sua presença, eu nunca vi um cavalheiro inglês que se parecesse mais com um ladrão muçulmano'.
} 
A situação é duplamente irônica se levarmos em conta o fato de Burton se textualizar a si mesmo, um inglês - estereotipados pelos colonizados como piratas e colonizadores - como um ladrão muçulmano e, ao mesmo tempo, fazê-lo partindo da perspectiva crítica de Salvador, para quem, como católico goês, o muçulmano tem sido, historicamente, um arquiinimigo.

Burton enfatiza, uma vez mais, sua autoridade desde que não só conhece o Outro, mas também suas brigas e diferenças. Por isso, pode enganar a todos, pois como homem de uma cultura superior pode entender a cultura do Outro ao ponto mesmo de passar-se por um Nativo. Além disso, Burton pode falar todas as línguas locais, enquanto Salvador nem sempre entende o que os outros Nativos falam. Assim, em um momento da aventura, Burton faz o fiel goês dizer que o 'Sahib' fala como um afegão enquanto ele, um goês, não pode entender o que dizem: "they engaged in deep conversation, through the medium of some tongue to me unknown" $(83)^{25}$.

$\mathrm{O}$ fato de Burton incluir este episódio no relato e textualizá-lo desta maneira, confere à narrativa uma perspectiva mais complexa, ao mostrar como constrói a si mesmo e ao Outro no que M. L. Pratt chama de a zona de contato: "espaços sociais onde culturas díspares se encontram, se chocam, se entrelaçam umas com as outras, frequientemente em relações assimétricas de dominação e subordinação como o colonialismo, o escravagismo" (1992:27).

Segundo a aventura sexual da narrativa - que lembra as de Don Juan Tenorio tentando raptar Dona Inés - o tal Lieutenant, ou seja, o mesmíssimo Burton, queria entrar no convento porque tinha se interessado por uma professora de Latim "a very pretty white girl, with large black eyes" (75) ${ }^{26}$. Sempre fingindo que é Salvador quem conta a estória, Burton faz com que dê todos os detalhes para logo questioná-lo enquanto sabedor de tanto:

'Pray, how did you learn all these particulars?'

'Ah, Sahib', replied Salvador, 'my master became communicative

\footnotetext{
25 'Eles entabulam uma conversa profunda através do uso de uma língua desconhecida para mim'.

26 'Uma moça branca muito bonita com grandes olhos pretos'.
} 
enough when he wanted my services' (78) ${ }^{27}$.

A resposta que Burton constrói a partir da perspectiva do criado demostra como o colonizador precisa do Nativo e, portanto, precisa acomodar seu comportamento à situação colonial. Revela também como não só o homem branco estava ciente da maneira como os Nativos eram tratados, mas também, como estes, embora submissos, tinham perfeita consciência da maneira como eram considerados pelos colonizadores e como lhes eram úteis, ao ponto de se considerar a si mesmo como o verdadeiro 'Outro'.

Quando, finalmente, a aventura não dá certo, porque, comicamente e, uma vez mais, lembrando as andanças de Don Juan Tenorio "o jovem oficial inglês”, ou seja, o próprio Burton, rapta uma freira em vez da professora de Latim, o Sahib quer saber o que deu errado e o pergunta a Salvador, mostrando como o colonizador sempre teme a traição do colonizado e este último é ciente disso: "In the morning I was called for examination, but my innocence bore me through the trial safely. My master naturally enough suspected me of having played some trick" (83) ${ }^{28}$.

Como sugerido anteriormente, o uso do ponto de vista nesta vinheta tem então uma dupla função: mostra como Burton, ciente de sua audiência na Inglaterra, representa-se de maneira a neutralizar a aventura sexual de sua viagem e revela também o que M. L. Pratt chama de perspectiva de contato: relações entre viajantes e visitados "não em termos de separação e segregação, mas em termos de presença comum, interação, entendimento e práticas interligadas freqüentemente dentro de relações assimétricas" (1992:32).

\section{Lugares e Pessoas}

Através desse conspícuo narrador, que representa o olho do império, Burton se apropria e reconstrói tudo aquilo que é de interesse para sua audiência metropolitana,

\footnotetext{
27 'Mas, como você soube de todos estes detalhes? Ah, Sahib!, respondeu Salvador, 'meu senhor era muito comunicativo quando precisava meus serviços'.

28 'De manhã fui chamado para ser examinado mas, a minha inocência, me conduziu sem perigo através do julgamento. Meu senhor, naturalmente, suspeitava que eu tivesse feito algum truque'.
} 
o que denuncia o seu locus de enunciação. À medida que avança, Burton cataloga lugares e pessoas de acordo com o que Edward Said chama de cultura e que em Cultura e Imperialismo define como significando duas coisas. Primeiro, "o saber popular sobre partes distantes do mundo [...], o conhecimento especializado de disciplinas como a etnografia, a historiografia, a filologia, a sociologia e a história literária" (1993:12). Em segundo lugar, acrescenta que "com o tempo a cultura vem a ser associada, muitas vezes de forma agressiva, à nação ou ao Estado; isso 'nos' diferencia 'deles', quase sempre com algum grau de xenofobia. A cultura, neste sentido, é uma fonte de identidade, e aliás bastante combativa" (1993:13).

Ambos os níveis da definição de cultura estão presentes no relato de Burton. Ao mesmo tempo em que traduz em sua narrativa as pessoas e os lugares que visita, todas as disciplinas mencionadas por Said ficam, em maior o menor grau, representadas segundo o interesse de Burton e daqueles para quem escreve. Da mesma forma, ao definir o Outro e seu local, o autor se define como cidadão de um dos maiores impérios do século XIX. É, justamente, a comparação implícita com a identidade britânica na representação do Nativo o que marca o tom antagônico da narrativa.

Segundo M. L Pratt, as cenas de chegada, que ela chama de zonas de contato, "são uma convenção de quase todos os tipos de relatos de viagens e são momentos potentes para a identificação das relações de contato" (1992:145). Quando Burton enxerga a costa goesa pela primeira vez, sua narrativa mostra uma dupla perspectiva: a do Nativo através de seu fiel Salvador, que ironicamente constrói como seu "sable Portuguese butler[...] ecstasied by his propinquity to home - sweet home [...] forgetting respect and self-possession in an elan of patriotism" $(15)^{29}$, e a sua própria, do colonizador, que é altamente crítica de tudo aquilo que contempla.

Assim como outros viajantes a procura do Oriente sonhado e apreendido em textos, ao tentar encontrar em Goa aquilo que percebera em Os Lusíadas e em seus

\footnotetext{
29 'Meu negro mordomo português [...] em êxtase, pela proximidade de seu lar - doce lar [...] esqueceu todo respeito e auto-controle em um ataque de patriotismo'.
} 
estudos de Camões, o autor tem seu apetite sensual traído. Quando ainda no navio, avista a costa de Goa, e diz:

Perched upon the topmast angle of our penthouse, we strain our eyes in search of the tall buildings and crowded ways that denote a capital: we can see nought but a forest of lanky cocoa-nut trees, whose stems are apparently growing out of a multitude of small hovels. Can this be Goa? (19) ${ }^{30}$.

A desilusão que Burton experimenta ao chegar a Goa - esse lugar complexo, onde a cultura do Oriente tinha se misturado à do Ocidente desde a chegada dos portugueses às suas costas no século XV - é um outro exemplo da atitude do Orientalista com respeito ao Oriente, segundo explica Edward Said: "O Oriente foi uma invenção européia e tem sido desde a antigüidade um local de romance, seres exóticos, memórias perturbadoras e experiências incomparáveis [...] O fato mais importante da visão européia de Oriente é a representação européia do lugar" (1978:1). Como o interesse ocidental no Oriente era principalmente textual, o Oriente 'real' nunca estava à altura das expectativas do viajante. Da mesma forma, a Goa que Burton contempla não tem muito a ver com aquela que tinha imaginado em suas leituras sobre Camões ${ }^{31}$, nem como denotam as suas palavras, com a magnificência das grandes metrópoles.

Aguçando o olho crítico do soldado inglês, a primeira imagem que Burton descreve da "once celebrated Portuguese capital" (15) é o Castelo de Agoada:

These defences, however, are built of stone, without any embankments of earth, and suggesting uncomfortable ideas of splinters $[\ldots]$ the southern prong, the

\footnotetext{
30 'Encaramados no mastil da nossa embarcação, aguçamos os nossos olhos procurando ver os altos edificios e ruas movimentadas de uma capital: só vemos uma floresta e uns fracos cocoteiros cujos troncos parecem sair de umas cabanas. É esta Goa?'.

${ }^{31}$ Em Goa: A Traveller's Historical and Architectural Guide, Antony Hutt explica que embora escrita no Oriente, Os Lusiadas não tem nenhuma passagem descritiva de Goa, como a Eneida não tem passagem descritiva de Roma. Mas, em suas páginas, encontramos uma brilhante representação da maneira pela qual os portugueses dessa época pensavam e a força que os levou a criar seu império (1988:70).
} 
'Cabo de Convento', is occupied, as its name shows, by a monastery instead of a fort. Moreover, none but a native general would ever think of thrusting an invading force through the jaws of the bay, when it might land with perfect safety and convenience to itself a few miles to the north or south $(16)^{32}$.

Seu olhar, desde o início, marca as diferenças entre a colonização inglesa e a portuguesa, mostrando a inferioridade dos últimos.

Nós reconhecemos dois eixos na maneira de Burton narrar Goa: o do passado, no sentido que procura o mítico e romântico da Velha Goa, e o do presente, na sua visita a Nova Goa ou Panjim. Ao descrever Panjim, Burton faz comparações racistas com a Irlanda, dando a seu relato um tom hostil: "That Panjim is a Christian town appears instantly from the multitude and variety of the filthy feeding hogs, that infest the streets. The pig here occupies the social position that he does in Ireland[...]" $(33)^{33}$. Assim nada do que ele ve em Panjim lhe agrada: "The streets are dusty and dirty, of a most disagreeable brick colour, and where they are paved, the pavement is old and bad" (33) ${ }^{34}$. Por sua vez, ele critica os militares, a educação, a vida social, as comidas. Tudo perde quando comparado com a Índia inglesa.

Para completar a descrição da cidade, e fazendo da sua burla dos Católicos o leit motiv do seu relato, Burton chama a atenção do leitor para o fato dos goeses baterem em suas mulheres. Caminhando pela rua, escuta gritos que o fazem pensar em um porco e pergunta ao seu fiel Salvador: "Salvador, what is that terrible noise - are they slaughtering a pig - or murdering a boy?' 'Nothing', replied Salvador, "nothing whatever, - some Christian beating his wife" (37) .

\footnotetext{
32 'As defesas, porem, estão construídas com pedras, sem diques de terra, e sugerem estilhaços [...] o exremo sul, o 'Cabo de Convento' está ocupado, como o seu nome indica, por um mosterio em vez de um forte. Ainda mais, só um general nativo poderia ter pensado em enviar uma força de invasão através da estreita bahia, quando poderia ter invadido com conveniência e segurança umas poucas milhas ao norte o ao sul'. 33 ' $\mathrm{O}$ fato de Panjim ser uma cidade Cristã fica refletido nos sujos porcos que infestam as rúas. $\mathrm{O}$ porco ocupa aqui a mesma posição social do que na Irlanda'.

34 'As ruas são poeirentas e sujas, de uma cor muito desagradável e, onde elas estão pavimentadas, o pavimento é velho e ruim'.

35 'Salvador, que é esse barulho? - estão matando um porco - ou assassinando um rapaz?' 'Nada', respondeu Salvador, 'nada, só um Cristão batendo na sua mulher'.
} 
O olhar de Burton não perde sua qualidade crítica nem quando visita a Velha Goa onde procura encontrar alguma marca de Camões. Suas impressões acerca dessa parte da cidade estão divididas em dois capítulos: "Old Goa as it was" e "Old Goa as it is" ". No primeiro capítulo, Burton, revelando seus interesses Orientalistas, procura por "MSS and publications upon the subject of Oriental languages and history, as connected with the Portuguese settlements" (41) ${ }^{37}$. Uma vez mais, porém, sentese desapontado. Ele dedica um capítulo inteiro aos Estudos Orientais da colônia Indo-Portuguesa, tecendo considerações acerca das publicações e da educação local, as quais encontra altamente deficientes: "the niceties of scholarship are unknown, good editions of the poets and authors being unprocurable here. Few Goanese write, the classical languages well; and though all can master the words, they seldom read deeply enough to acquire the idiom" (141) ${ }^{38}$.

O motivo principal da pobreza dos estudos Orientais tem a ver, segundo Burton, com o enfraquecimento da propagação do Catolicismo pelos portugueses, único motivo pelo qual se interessaram pelas línguas locais. O que pode ser lido entre as linhas nesta parte do relato é que ao enfatizar o limitado escopo dos estudos Orientais portugueses, Burton tem ocasião de falar da magnificência dos mesmos estudos apresentados pelos ingleses. Ao fazer isto, uma vez mais, mostra a superioridade britânica e claramente agrada a sua audiência:

Our case is very different from theirs. In addition to religious incentives, hundreds of our nation have more solid and powerful inducements to labour held out to them [...] Within the last few years we have more or less facilitated the acquisition, and rifled the literature between thirty and forty eastern dialects - a labour of which any nation would be proud (151-152) ${ }^{39}$.

\footnotetext{
36 “A Velha Goa como era antes e a Velha Goa como é agora'.

37 'Manuscritos e publicações, sob o tema de línguas e história Orientais, relacionados com a colonização portuguesa'.

38 'os refinamentos da pesquisa intelectual são desconhecidos, as boas edições de poetas e autores impossíveis de encontrar. Poucos goeses escrevem bem as línguas clássicas; embora todos possam produzir algumas palavras, raramente lêem o suficiente para adquirir o idioma'.

39 'O nosso caso é bem diferente. Além dos incentivos religiosos, centenas de pessoas na nossa nação recebem poderosas ajudas [...] Nos últimos poucos anos, temos facilitado a aquisição e estudado a literatura de trinta a quarenta dialetos orientais - tarefa da qual qualquer nação sentir-se-ia orgulhosa'.
} 
Finalmente, está en route às ruínas: "We can start as soon as we like for the 'ruin and the waste" (43) $)^{40}$. Burton relata a seguinte parte da sua viagem a partir das convenções da literatura romântica predominantes no século XIX, fazendo o mesmo que ele criticara nos "poetical authors" ou "lady prosers" ao sentimentalizar o Oriente.

Como seu leitor, Burton conhece Goa através de textualizações anteriores. Então, enquanto o navio os conduz a Velha Goa, ele faz uma recapitulação dos relatos de outros viajantes sobre a cidade. Essa intertextualidade é altamente funcional, uma vez que não só cria em seu leitor expectativas sobre a cidade a ser visitada, como também confere maior verosimilhança à sua narrativa, ao mencionar outros viajantes ocidentais no Oriente: "The descriptions of Goa in her palmy days are, thanks to the many travellers that visited the land, peculiarly graphic and ample" (46) ${ }^{41}$. Ao outro nível, torna a sua prosa mais empolgante já que faz explicita referência aos elementos de aventura, amor e exotismo, típicos desse gênero de relatos e que ele diz menosprezar.

Burton começa com a viagem de Linschoten, que esteve em Goa em 1583, e a descreve com todo o esplendor esperado de uma cidade do Oriente: "the finest, largest and most magnificent city in India: its vilas merited the title of palaces, and seemed built for the purpose of displaying the wealth and magnificence of the erectors. [...] The viceroyalty of Goa was one of the most splendid appointments in the world" (46-47) ${ }^{42}$.

Já nas narrativas de Monsieur Tavernier, Baron de Aubonne, que visitou Goa por duas vezes, a primeira em 1641, "the city was declining rapidly" (47). Porém, o esplendor e perigo associado com o Oriente ainda estavam presentes. É recebido pelo Vice-rei Don Philip de Mascaregnas, que é textualizado como "a most expert poisoner" e "[the] richest Portuguese noble that ever left the East, especially in

\footnotetext{
40 'Podemos começar, imediatamente, o nosso caminho 'às ruinas e a desolação'.

41 'As descrições de Goa em seus dias gloriosos são, graças aos viajantes que têm visitado a terra, particularmente gráficos e amplos'.

42 'A mais sofisticada, maior e magnifica cidade na India: as suas vilas merecem o título de palácios e parecem construídas com o propósito de mostrar a riqueza e magnificência dos construtores. [...] A vice-realeza de Goa era um dos mais esplêndidos destinos no mundo'.
} 
diamonds, of which he had a large parcel containing none but stones between ten and forty carats weight" (48-49) ${ }^{43}$, um verdadeiro tirano Oriental.

O próximo viajante, o físico francês Dellon, segundo Burton, fez de sua viagem uma aventura amorosa, ao ter um caso com uma dama portuguesa que era também amante do governador e do secretario da Inquisição.

Contudo, Burton parece particularmente empolgado com a narrativa do Capitão Hamilton, que representa os goeses de uma maneira mais afim com sua própria narrativa: "a pack of the most atrocious hypocrites in the world" e "most zealous bigots" (54-55) ${ }^{44}$. Escolhe, então, aquelas passagens em que Hamilton mostra o antagonismo entre protestantes e católicos, relevando o número de igrejas e mosteiros e ironizando os milagres atribuídos a São Francisco Xavier:

He compares the holy corpse to that of a 'new scalded pig', opines that it is a 'pretty piece of wax-work that serves to gull the people', and utterly disbelieves that the amputated right-arm, when sent to Rome to stand its trial for sainthood, took hold of the pen, dipped it in ink and fairly wrote 'Xavier" in full view of the sacred college $(55)^{45}$.

Apelando ao interesse de seu leitor pelo exótico, Burton reproduz a estória que Hamilton narra sobre uma certa Dona Maria, dama portuguesa que, travestida de homem, viajou a Goa a procura do indivíduo que lhe tinha quebrado promessa de matrimônio. Finalmente, não só casa com o pretenso fujão, após desafio em duelo, mas, algum tempo depois, durante a guerra dos Maharatta, encabeça uma revolta contra os infiéis, cortando-os em pedaços.

\footnotetext{
43 'Um envenenador muito experto' e 'o mais rico nobre português no Oriente, especialmente em diamantes, dos quais possuía pedras entre dez e quarenta quilates de peso'.

44 ‘Um bando dos mais atrozes hipócritas do mundo' e 'os mais fervorosos fanáticos'.

45 'Ele compara o corpo sagrado a um 'porco escaldado'. Opina que 'é um pedaço de cera que serve para enganar às pessoas'; definitivamente não acredita que quando o braço direito amputado foi enviado a Roma para ser submetido ao julgamento de Sua Santidade, tomou a pena, a submergiu em tinta e escreveu 'Xavier' à vista dos sagrados colegas'.
} 
Finalmente, o autor conclui sua revisão da textualização de Goa feita por outros europeus através dos séculos, com uma breve referência ao Rev. Mons. Cottineau de Kleguen, missionário francês que morreu em Madras em 1830. Burton interpreta o seu 'Historical Sketch of Goa' como "a useful [...] guide-book to the buildings, and gives much information about ecclesiastical matters' (57) ${ }^{46}$. Seu ponto fraco, segundo Burton, seria o fato de, revelando seu fanatismo católico, defender " "the Jesuits' peculiar process of detaching the pagans from idol worship, by destroying their temples and pagodas" (57) ${ }^{47}$.

Ao chegar a Velha Goa durante a noite, Burton começa sua própria textualização do lugar. Parece hipnotizado pelas ruínas e, paradoxalmente, sua narrativa adquire nuances góticas e românticas, denunciando a tradição literária que ele mesmo tinha criticado. Consequentemente, a atitude hostil do texto parece sumir e dar lugar ao discurso do Romantismo que evoca ruínas misteriosas ao luar e revela uma profunda melancolia:

When the moon began to sail slowly over the eastern hills, we started on our tour of inspection[...] A more suggestive scene could not be conceived than the utter desolation which lay before us. Everything that met the eye or ear seemed teeming with melancholy associations; the very rustling of the trees and the murmur of the waves sounded like the dirge for the departed grandeur of the city $(59)^{48}$.

Ao caminhar entre as ruínas, assume o 'pensive mood', característico dos poetas românticos que, em momentos como esse sentem-se mais próximos do mistério do universo e assim, como eles, Burton também reflete sobre a condição humana: “What

\footnotetext{
46 'Burton interpreta o seu 'Esboço Histórico de Goa' como 'um guia útil aos edificios e oferece muita informação sobre temas eclesiásticos’.

47 'O proceso peculiar dos Jesuitas de separar os pagãos da veneração de ídolos através da destrução de templos e pagodes'.

48 'Quando a lua começou a navegar sob as colinas no leste, começamos a nossa visita de inspeção [...] Uma cena mais sugestiva, que a desolação na nossa frente, não poder-se-ia ser concebida. Tudo aquilo que surprendiam os nossos olhos e os nossos ouvidos sugeriam uma grande melancolia; o murmúrio das árvores e as ondas soavam como um canto funebre à passada grandeza da cidade' .
} 
a contrast between the moonlit scenery of the distant bay, smiling in all eternal Nature's loveliness, and the dull grey piles of the ruined or desolate habitations, the short-lived labours of man" (61) ${ }^{49}$.

Neste tom quase mórbido, representa a Velha Goa, no melhor estilo gótico, como "the city of the dead" (58), completando o seu relato com a descrição do "solitary jackal" (61) que cruza a noite e fazendo referência à maldição, um dos principais ingredientes da literatura gótica, que teria provocado a destruição da cidade: "A curse seems to have fallen upon it; not a shrub springs between the fragments of stone, which, broken and blackened with decay, are left to encumber the soil, as unworthy of being removed" (62) ${ }^{50}$. O registro do vocabulário utilizado na descrição da paisagem sombria, aliás, mostra Burton ciente da qualidade do seu texto e das convenções literárias aludidas anteriormente.

A narrativa romântica completa-se com seu elemento principal: a trágica estória de amor, neste caso a de um yogee, a quem encontram próximo das ruínas e que está prestes a morrer. Quando perguntam qual sua doença, responde que trata-se de " a disappointment in an affaire de coeur" (65), o que Burton ironicamente interpreta como "the cause of half of aesceticism in the East" (65) ${ }^{51}$.

O yogee lhes conta que apaixonara-se - "as Orientals only can" (65), segundo Burton - pela mulher de um brâmane. Quando este morre, ela está destinada a seguílo de acordo com o rito Suttee. Vestido de amarelo - a cor vestida pelos Hindus quando estão prestes a fazer algo desesperado - e montando um cavalo, tenta resgatar a mulher da pira onde está por consumir-se. Uma flecha certeira, contudo, atravessa o coração da mulher que morre instantaneamente nos braços de seu namorado.

\footnotetext{
49 'Que contraste entre a cena ao luar da baia distante sorrindo na beleza eterna da Natureza, e as desoladas e cinzas ruinas dos edifícios, mostra da finita obra do homem'.

50 'Uma maldição parece ter caido sobre a cidade; nem um arbusto cresce entre os fragmentos de pedra os quais, quebrados e enegrecidos pela decadência, são deixados para obstruir o solo, como se não merecessem ser removidos'.

51 'Uma desilusão nos assuntos do coração' [...] 'a causa da metade do ascetismo na India'
} 
Segundo a nossa leitura, esses capítulos do relato partilham da textualização da Índia como "Romântica e espiritualista" (Inden 1994: 66), levando em conta as suas práticas ascéticas e místicas, fato que colocaria Burton dentro do locus enunciativo dos Orientalistas e suas visões estereotipadas de Oriente.

Mas, quando os primeiros raios do dia iluminam o lugar, o tom romântico desaparece e o estilo da narrativa muda radicalmente. Uma vez mais, a crítica ressurge: "Old Goa has few charms when seen by the light of day" (68) ${ }^{52}$. O que ao luar aparecia entre mágico e sobrenatural agora é quase grotesco.

Burton descreve as igrejas e obras de arte da Velha Goa em um estilo cumulativo e alusivo, que seria uma adaptação do que Ivan Teixeira chama de "estilo asiático" (1999:311), e que, em outro nível, mostra a influência de suas leituras de textos orientais.

Adotando um tom de desrespeito, por meio do qual ele implicitamente compara o que vê com o seu equivalente europeu, o autor narra que " as there is no such thing as coloured marble in the country, parts of the walls are painted exactly in the style of a small cabaret. The frescoes are of the most grotesque description" (69-70) ${ }^{53}$. Das pinturas dos santos, ele diz que "the Jesuit martyrs upon the walls of Saint Francis, are absolutely ludicrous. Boiled, roasted, grilled and hashed missionaries, looking more like seals than men, gaze upon you with an eternal smile" (70) $)^{54}$. O único elemento que parece ter restado da paisagem gótica e sobrenatural é, ironicamente, uma referência a Frankenstein: "Very like the paintings is the sculpture: it presents a series of cherubims, angels and saints whose very aspect makes one shudder, and think of Frankenstein" (71) ${ }^{55}$.

\footnotetext{
52 'A Velha Goa tem poucos encantos quando vista à luz do dia'.

53 'como não há mármore de cor no país, partes das paredes são pintadas no estilo de um pequeno cabaré. Os afrescos são grotescos'.

54 'Os mártires Jesuitas nas paredes de São Francisco, são absolutamente absurdos. Misionários fervidos, assados, grelhados e picados, que se parecem mais com focas do que com homens, olham com um eterno sorriso'.

55 'Parecidas com as pinturas são as esculturas: apresentam uma série de querubins, anjos e santos cujo aspecto faz o espectador tremer e lembrar do Frankenstein'.
} 
Acreditamos que a descrição que Burton faz de Goa reflete, citando Said, a maneira agressiva pela qual a cultura é associada com o conceito de nação e estado: a cultura portuguesa na Índia sempre perde quando comparada com a Índia inglesa. Ao mesmo tempo, esse tipo de narrativa não só marca as diferenças entre Burton e a cultura local, mas o coloca cada vez mais próximo da sua própria audiência back home.

Da mesma maneira, na textualização de Calicut e Malabar, as próximas cidades que ele visita, sua narrativa é categórica ao considerar aspectos históricos, geográficos, etnográficos e sociais, sempre mantendo a comparação implícita com o europeu, mas de forma menos crítica pelo fato dele estar em colônia inglesa. Contudo, o que sempre pode ser lido entre as linhas é que a Índia que ele vê, embora fascinante, está "em plena decadência quando comparada com seu passado dourado" (Inden 1994:72).

Ao chegar a Calicut, questionando a credibilidade da história do Oriente devido a seu caráter fantasioso, ele narra que "There is a tradition amongst the natives of the country that the ancient Calicut was merged beneath the waves; but in the East tradition is always a terrible romancer" $(170)^{56}$, diferente das narrativas do ocidente onde a história impõe-se sobre a fantasia e, portanto, é mais veraz. Implicitamente, Burton está adotando a atitude do Orientalista que assume conhecer o Outro e a sua história muito melhor do que esse Outro se conhece a si mesmo.

Porém, paradoxalmente, ele parece preferir acreditar na epopéia histórica ficcionalizada no poema de Camões do que na historiografia local: "So we will still continue to believe that here old Da Gama first cast anchor and stepped forth from his weather-beaten ship, at the head of his mail-clad warriors upon the land of promise" (170) ${ }^{57}$.

Burton textualiza Calicut como uma verdadeira zona de contato na qual os europeus e os asiáticos, 'nós' e 'eles', aparecem misturados, em uma atitude de desconfiança por parte do Nativo e crítica por parte de Burton: "The population apparently regards us with no friendly feeling. Moslems, Hindoo, all have scowls

\footnotetext{
56 'Há uma tradição entre os nativos do país que a antiga Calicut foi submersa embaixo das ondas. Mas, no Leste, a tradição é uma terrível romancista'.

57 'Continuaremos acreditando que aqui o velho Da Gama foi o primeiro a lançar âncora e desceu de seu maltratado navio, encabeçando seus guerreiros vestidos, com armaduras, na terra prometida'
} 
upon theirfaces, and every man, moreover, carries a knife conveniently slung to his waistband" (174-175) ${ }^{58}$.

O olhar de Burton não se limita a visualizar o exterior, mas também penetra nos interiores com a mesma liberdade com que observa a paisagem. Segundo David Spurr (1993), a literatura ocidental tem uma tradição de penetrar nos espaços interiores dos não europeus. Assim, quando Burton é convidado pelo Samiry Rajah "the Zamorin of Camoens" (172) a visitá-lo em seu palácio, seu olhar autoritário e crítico reconstrói a sala para seu público europeu, remarcando as diferenças culturais e indiretamente aludindo ao bom gosto inglês que compartilha com sua audiência: "The room was small and choked with furniture; chairs, tables, clocks, drawers, washingstands, boxes, book-shelves, and stools, were arranged, or rather piled up around it, with all the effect of an old curiosity-shop" (178) ${ }^{59}$.

Burton termina sua descrição crítica da sala fazendo referência aos objetos ocidentais, típicos das zonas de contato, tidos pelo Rajá como símbolos de refinamento, os quais, tanto para ele como para sua audiência, são outra prova de que o Outro, embora tentando expressar sua simpatia pelo Ocidente, não compreende os seus símbolos e considera quinquilharias como objetos de valor:

The walls exhibited a collection of the cheapest and worst of coloured prints our late gracious queen dangling in dangerous proximity to the ferocious-looking Beau Sabreur, and La Belle Americaine occupied in attentively scrutinizing certain diminutive sketches of Richmond Hill, and other localities, probably torn out of some antiquated Annuals (178) ${ }^{60}$.

\footnotetext{
58 'Aparentemente, a população não nos vê de maneira amigável. Muçulmanos, hindus, todos têm rostos carrancudos e cada homem leva uma faca na cintura'

59 'O quarto era pequeno e carregado de móveis: cadeiras, mesas, relógios, gavetas, lavatórios, caixas, estantes de livros, bancos estavam colocados ou, melhor, empilhados, provocando o efeito de uma loja de curiosidades'.

60 'As paredes exibiam uma coleção das piores e mais baratas pinturas - a nossa graciosa rainha anterior pendurada numa proximidade perigosa da feroz Beau Sabreur e la Belle Americaine ocupada em escrutar detalhadamente uma série de desenhos diminutos de Richmond Hill, e outras localidades, provavelmente tiradas de algum Anuário antigo'.
} 
Ao chegar a Malabar, pela primeira vez, Burton chama a atenção do leitor para a beleza da paisagem e para a riqueza do solo e descreve a cidade como uma comunidade pastoral, antiga e tradicional:

Substantial pagodas, and the prettiest possible little villages crown the gentle eminences that rise above the swampy rice lands, and the valleys are thickly strewed with isolated cottages and homesteads, whose thatched roofs, overgrown with creepers, peep out from the masses of luxuriant vegetation... (190) ${ }^{61}$.

Embora diga que suas casas são muito melhores do que outras em qualquer parte da Índia (desde que já se encontra no território da Índia Inglesa); que cada uma delas tem uma pequena plantação: "Each tenement has its own croft planted with pepper, plantains, and the betel vine..." (190) ${ }^{62}$, é interessante notar a dificuldade que encontra para fazer qualquer tipo de elogio à habilidade do nativo a quem critica pela sua primitiva e pouco efetiva maneira de trabalhar:

The practical husbandry of Malabar is essentially rude, and yet in few countries have we seen more successful cultivation. The plough is small, of simple form, and so light, that it merely scratches the ground; a pair of bullocks, or a bullock and a woman or two, are attached to the log, and while the labourer dwadles over his task, he chaunts monotonous ditties to Mother Earth with more pious zeal that industry (192) ${ }^{63}$.

Os cultivos, porém, não são o resultado do seu trabalho, mas das condições naturais do solo, já que se utiliza de ferramentas primitivas de uma maneira quase bárbara. Além disso, ele os apresenta como brutais ao colocar as suas mulheres na mesma condição que as bestas.

\footnotetext{
61 'Grandes pagodes e as mais bonitas e pequenas vilas coroam as cimas que surgem sob os campos de arroz e os vales salpicados por cabanas isoladas cujos tetos, cobertos por trepadeiras, aparecem na luxuriosa vegetação...'.

62 'Cada morada tem a sua própria horta com pimentão, ervas e betel vermelho'.

63 'A agricultura de Malabar é muito primária. Porém, em poucos países temos visto melhores cultivos. O arado é pequeno, de forma simples e tão leve que só arranha o solo; um par de bois ou um boi e uma mulher ou dois, são atados a um tronco de madeira e, enquanto o agricultor faz o seu trabalho, entoa cantinelas monôtonas à Mãe Terra com mais piedade do que habilidade'.
} 
Implicitamente, este tipo de reflexão legaliza a presença do colonizador, pois este não só é capaz de perceber e entender a situação, como tem também os meios para modificá-la. Esse é o mesmo critério que Burton parece seguir quando descreve os rios e lagoas que atravessam a região: "A great public use could be made of these inconvenient streams"'192) $)^{64}$. O suplemento silenciado por meio do uso da voz passiva implica que eles, ingleses, têm a inteligência e a tecnologia necessária para usar a natureza em seu proveito.

Esta situação vem exemplificar as palavras de Inden, quando argumenta que para o Ocidental o "Oriente não tem capacidade de atuar com racionalidade. Não partilham sequer da noção de indivíduo, liberdade ou ciência. É por isso que precisam da presença do colonizador" (1994:6).

Ainda um outro aspecto de Malabar que Burton reconstrói em seu texto, uma vez mais denunciando sua visão de Orientalista que se interessa mais pelo remoto, que ele considera exótico, do que pelo presente da cidade visitada, é a organização feudal da comunidade no passado e seu sistema de renda: "We propose to give a somewhat detailed account of the chief items composing the curious revenue of the Hindoos rajahs and chiefs in the olden times" (195) ${ }^{65}$. Segundo Inden, o interesse dos ocidentais na organização feudal da India tem a ver com a construção dos Orientalistas da sociedade Indiana como um exemplo de despotismo Oriental.

Faz assim uma larga classificação das fonte de renda do rajá dividida em vinte cinco categorias, chamando a atenção para o sistema pré-colonial de estratificação social em termos de casta, possessão da terra, endogamia marital, (Mascarenhas 1999: 151), sempre apontando para seu caráter exótico. Esse exotismo é o resultado da descontextualização do discurso. No relato de Burton, como no caso de outros Orientalistas, segundo aponta Inden, "práticas econômicas e políticas aparecem esquisitas quando desconstruídas a partir de uma perspectiva estrangeira. Não são, con-

\footnotetext{
64 'Um grande uso público poder-se-ia obter desses inconvenientes córregos'.

65 'Tentaremos dar um relato detalhado dos elementos principais que compõem a curiosa fonte de renda dos rajás e chefes hindús nos velhos tempos'.
} 
tudo, práticas tão estranhas quando se descobre que têm uma função útil, respondendo a uma grande variedade de necessidades psicológicas e sociais" (1994:52).

Burton continua com uma longa descrição da hierarquia feudal dos Brâmanes em Malabar, sempre apresentando-a, desde uma visão eurocêntrica, como organização anárquica:

The anarchy introduced by this complicated variety of feudalism soon compelled the hierarchy to call in the aid of the Bejanuggur, or, as it is commonly termed, the Anagundy government, and the latter, at the solicitation of the Brahamans, appointed a Peroomal, or Viceroy whose administration was limited to the term of twelve years $(205-206)^{66}$.

Embora a linguagem empregada na descrição seja quase técnica, acreditamos que nas entrelinhas da complicada e detalhada narrativa da sociedade Bramânica exista o contraponto, a partir de uma perspectiva eurocêntrica, entre o que Inden chama de "racionalidade organizada do mundo" do Ocidente e a "imaginação desordenada” de Oriente, o 'nós' e ‘eles' que Said pontualiza na sua definição de cultura.

Finalmente, Burton chega a Ootacamund, a colônia inglesa nas Nielgherries. Com muita ironia, ele parece adotar o tom do gentleman tourist que ele mesmo critica, levando o leitor quase pela mão numa percorrida pelo lugar mostrando a paisagem, a cidade, e as atividades que podem ser feitas em 'Ooty' que promete converter-se, em poucos anos, em "the largest European settlement in India” (285) ${ }^{67}$.

Ele a descreve como "a perfect anomaly" (289) devido às características ocidentais da cidade no coração de Oriente. Desde as casas "a cold place in a hot country" (288) ${ }^{68}$, a comida "[the] mutton had a flavour which you did not recollect in India" (290) ${ }^{69}$, até o

\footnotetext{
66 'A anarquia introduzida por esta complicada variedade de feudalismo logo os obrigou a procurar a ajuda do Bejanuggur ou, como é comunmente denominado, o governo Anagundy. Esse último, por pedido dos Brâmanes, nomeu o Peroomal, ou vice-rei cuja administração foi limitada a doze anos'.

67 'A maior colônia européia na Índia'.

68 'Um lugar frio em um país quente'.

69 'O carneiro tinha um gosto não comum na Índia'.
} 
clima frio "You decided that the Neilgherries are, after all, a tame copy of the Alps and the Pyrenees" $(291)^{70}$ tudo é representado como uma falsa cópia da Inglaterra.

A cena de partida partilha do mesmo tom antagônico do relato, ironizando, implicitamente, cenas similares em relatos de viagens: "[t]urning round upon the saddle, we cast one last scowl upon Ootacamund, not, however, without a grim smile of joy at the prospect of escaping from it" $(368)^{71}$.

Todos esses exemplos, com a excepção de Ooty, vêm demostrar como Burton constrói o Oriente, para sua audiência européia, sempre levando em conta a idéia de Ocidente e, em particular a Inglaterra, como "the epitome of the Modern". Para isso, segundo Inden, o Ocidente precisa de uma imagem fixa da India, sempre antiga, como aparece no relato de Burton, ao fim de afirmar sua própria superioridade.

Embora sua viagem não fosse científica, acreditamos que o discurso de Burton, em sua descrição do Outro, reflete o forte desejo de verdade desse tipo de estudos uma vez que estava ciente que eram foco de interesse público e serviam de meio pelo qual cidadãos europeus se relacionavam com outras partes do mundo. Como sugerido anteriormente, ao descrever os Nativos, Burton o faz de tal forma que os torna compreensíveis a sua audiência na Inglaterra. Aliás, como no caso das cidades que visita, ele as textualiza em forma de catálogo, denunciando, uma vez mais, a qualidade das narrativas anglo-indianas do século XIX que, frente ao problema de representar a cidade colonial a partir de uma perspectiva Ocidental, reduziam experiências culturais a extensas listagens (Suleri 1992: 29-32).

Dessa maneira, ficam confirmadas, uma vez mais, as palavras de Edward Said quando afirma que "as culturas sempre têm tido o desejo de transformar outras culturas para percebê-las, não pelo que são, mas pelo que deveriam ser a partir da ótica do receptador" (1978:67). Todos os povos que Burton encontra a medida que avança

\footnotetext{
70 'Os Nilgherries são uma cópia insípida dos Alpes e dos Pirineos'.

71 'Virando na sela damos uma última olhada a Ootacamund mas não sem um sorriso de alegria por, finalmente, escapar dela'.
} 
são implicitamente comparados com os europeus, refletindo o que Inden chama de "negação de contemporaneidade" ${ }^{72}$ (1994:53).

Se Burton, por meio do olhar imperial, "impõe um contorno à identidade do Outro e usa esse contorno para negar a alteridade" (Menezes de Souza 1997:76), ao mesmo tempo, também se mimetiza com a sua cultura, mostrando o processo de transculturação da colônia para a metrópole (Pratt 1992:31) fato que fica refletido na sua classificação do Nativo em termos não só de "raças" más também de "castas",

Assim, ao descrever a sociedade goesa, Burton primeiro a critica em termos do conceito de hibridismo racial para logo após considerá-la em termos de castas. Ele argumenta duramente contra a política dos casamentos inter-raciais, entre portugueses e nativos, propiciados por Afonso de Albuquerque, como parte da sua política de integração a qual era inteiramente inédita na Europa desse tempo. Enquanto os ingleses favoreciam uma política puramente colonialista, os portugueses estavam a favor da integração, como uma maneira de expandir-se na Ásia e estabelecer um estado europeu (Devi et alii1971:12). Paradoxalmente, ao fazer isto, os colonizadores portugueses introduziram discriminações religiosas colocando os não cristãos em situação de desvantagem nos campos educativos e sociais.

Burton, ironicamente, define Albuquerque, numa nota de rodapé, como "the greatest hero of Portuguese Asia" mas também explica que seu grande erro (a política de integração) deve-se ao fato de só ter vivido na Índia por seis anos e de ter aplicado tal política a partir da teoria. Em outras palavras, só a maior ignorância do tema poderia tê-lo levado a favorecer o inter-racialismo.

Segundo Burton, a política de integração junto com a conversão massiva dos Nativos ao Catolicismo são, entre outros, os motivos que provocaram a queda do império português na Índia e que marcam uma das diferenças mais radicais com a colonização inglesa:

\footnotetext{
${ }^{72}$ Inden define 'the denial of coevalness' como 'a major device of an anthropological discourse to define the otherness of the people or cultures at the time that they are being brought into relation with European states' (53).

${ }^{73}$ É preciso ressaltar que Goa and the Blue Mountains foi publicado oito anos antes que Charles Darwin publicasse A Origem das Espécies em 1859.
} 
Governed by a succession of viceroys, many of them the bravest and wisest of the Portuguese nation, Goa soon rose to a height of power, wealth, and magnificence almost incredible. But the introduction of the Jesuits, the Holy Tribunal and its fatal offspring, religious persecution; pestilence, and wars with European and native powers, disturbances arising from an unsettled home government, and, above all things, the slow but sure workings of the short-sighted policy of the Portuguese in intermarrying and identifying themselves with Hindoos of the lowest castes, made her fall as rapid as her rise was sudden and prodigious (44-45) ${ }^{74}$.

Falando da miscigenação, Burton agradece aos céus que a política de integração racial não tenha sido aplicada pelo governo inglês: "May Heaven preserve our rulers from following their example! In our humble opinion, to tolerate it is far too liberal a measure to be a safe one!" (88) ${ }^{75}$. O texto de Burton reflete uma das posturas no século XIX sob hibridismo racial. Segundo explica Young:

[a ] miscegenação resulta em uma comunidade de mogréis que, por sua vez, produzem um caos racial, em outras palavras, geram a corrupção dos originais, que, degenerados e degradados, subvertem o vigor e a virtude da raça pura com a qual eles entram em contato (1995:18).

Da mesma maneira, conforme o que Young chama de "versão negativa da teses de amalgamação" ${ }^{76}$ (1995:18), Burton entende a integração racial não como fusão e assimilação, mas como contrafusão e disjunção. Assim, para ele, mistura não traz tolerância, mas desconfiança e ressentimento. Mostrando uma vez mais, a superio-

\footnotetext{
74 'Governada por uma sucessão de vice-reis da nação portuguesa, muitos deles bravos e sabios, Goa logo alcançou um alto nível de poder, riqueza e magnificência quase incríveis. Mas a introdução dos Jesuítas, a Santa Inquisição e sua fatal consequência: a perseguição religiosa. Pestes, guerras com poderes nativos e europeus, disturbios como resultado da intranquilidade no governo em Portugal e, particularmente, a politica dos casamentos interraciais junto com a identificação com os hindus das castas mais baixas provocou a sua queda tão rapidamente como a sua prodigiosa ascensão'.

75 'Que os Céus não permitam que nossos governantes sigam o seu exemplo! Na nossa humilde opinião, a tolerância é uma política demasiado liberal para ser segura!'

${ }^{76}$ Young explica que a palavra 'miscegenação' só foi inventada no ano 1864. Até esse momento a palavra que era convencionalmente usada para se referir a fusão de raças era ‘amalgamação’ (9).
} 
ridade da colonização inglesa sobre a portuguesa em relação ao problema da miscigenação, Burton explica que "no Anglo-Indian Nabob sixty years ago ever thought less of a 'nigger' than a Portuguese officer does now" (86) ${ }^{77}$.

O autor utiliza o termo "mongrel”, não só para referir-se aos filhos de casamentos inter-raciais, mas também para identificar aquelas famílias que tinham morado na Ásia por mais de uma geração, implicitamente definindo o hibridismo como resultado do determinismo geográfico e climático: "for although[...] there is no mixture of blood, still there has been one of air or climate, which comes to the same thing' [...] They presently degenerate, from the slow but sure effects of a debilitating climate, and its concomitant evils, inertness, and want of excitement" (89) ${ }^{78}$.

Tanto os casamentos inter-raciais como a simples permanência por um tempo prolongado na zona de contato provocam o enfraquecimento da raça. Ao visitar a colônia portuguesa, Burton reflete sobre a inglesa e adverte do perigo de "going native”. Segundo ele, o estabelecimento de famílias inglesas na Índia não é prudente, pois pode causar a debilidade do império, como resultado da mistura racial:

Our Empire in the East has justly been described as one of opinion, that is to say, it is founded upon the good opinion entertained of us by the natives, and their bad opinion of themselves. In the old days of the Honourable East India Company, when no Englishman or Englishwoman was permitted to reside in India, without formal permission, the people respected us more than they do now $(157)^{79}$.

A perda de respeito, por sua vez, provocaria o levante dos indianos que "if they could be unanimous for a day [...] might sweep us from their country as dust before

\footnotetext{
77 'Nenhum Nawab Anglo-Indiano, sessenta anos atrás, considerou menos um 'negro' do que hoje um oficial português'.

78 'Porque embora não há mistura de sangue, ainda há uma mistura de clima que é o mesmo' [...] Eles degeneram-se devido ao lento mas efetivo enfraquecimento produzido pelo clima que provoca inércia e falta de energia'.

79 'O nosso Império no leste tem sido descrito como um de opinião, ou seja, fundado na boa opinião que os nativos têm de nós, e a má opinião que têm de si mesmos. Nos velhos tempos da Honorável Companhia das Indias Orientais, quando não era permitido para nenhum homem ou mulher inglesa morar na India, sem uma autorização, éramos mais respeitados do que agora'.
} 
a whirlwind" (158) ${ }^{80}$. Este fato explicaria porque Burton, embora tenha se mimetizado com a cultura muçulmana, ao ponto de ser um iniciado no sufismo (como demonstra Edward Rice em sua biografia), nunca perde seu olhar europeu.

Em um segundo momento, Burton textualiza a população de Goa em termos da sociedade de "castas" a qual está baseada na idéia da "comunidade de raças". Dessa maneira, ele une a teoria do hibridismo racial, manifestando seu locus enunciativo Ocidental, ao conceito hindu da pureza das castas, revelando a influência do Oriente no seu pensamento: "[t]he population of Goa is composed of three heterogeneous elements, namely, the pure Portuguese, black Christians and the heathenry. A short description of each order will, perhaps, be acceptable to the reader" $(85)^{81}$.

Quanto aos portugueses, ainda que ocupando uma posição de privilégio com respeito aos Nativos, Burton sempre os coloca em uma relação assimétrica comparados com os ingleses, devido ao fato de serem considerados de uma cultura periférica. $\mathrm{O}$ autor os apresenta em termos das suas práticas sociais, as quais considera deficientes, equiparando assim diferenças sociais a diferenças raciais. Em outras palavras, ele aplica na sua descrição de uma sociedade ocidental, considerada menor, o mesmo patamar utilizado pelos Orientalistas ao definir a India:"The stranger who visits Goa persuaded that he is to meet with the freedom of manners and love which distinguish the people of the continent, will find himself grievously mistaken" $(90)^{82}$.

Seguindo com a sua descrição da população de Panjim, em termos de casta, Burton descreve os cristãos nativos de Goa, the Black Christians, apontando que, em geral são hindus de casta mais baixa e que, embora tenham mudado as vestimentas e religião, "[they] retain to a wonderful extent the ideas, prejudices,

\footnotetext{
80 'Se eles pudessem se unir por um dia, nos varreriam do seu país como pó no remoinho'.

81 'A população de Goa é composta por três elementos heterogêneos: os portugueses puros, os Cristãos negros e os heréticos. Uma descrição de cada um deles pode ser aceitável para o leitor'.

82 'O estrangeiro que visita Goa persuadido que encontrará os modos das pessoas do continente logo perceberá seu erro'.
} 
and superstitions of his ancient state' [...] This race is decidedly the lowest in the scale of civilized humanity we have yet seen" (102-103) ${ }^{83}$.

Da mesma forma, ao referir-se aos "pagãos de Goa", the heathenry, mostra uma vez mais a perspectiva bramânica em sua classificação de povos ao observar que os Muçulmanos "puros" "appear superior beings by the side of the degenerate native Christians" (106) ${ }^{84}$, desde que, como assinalado anteriormente, a mistura de raças, segundo Burton, tem provocado uma grande desordem social, ao ponto de, como ironicamente coloca, considerar que "all men are equal" (106).

Burton também faz uma descrição da sociedade de "Ooty", como é chamada familiarmente, aplicando, ironicamente, a divisão brâmanica de castas. Fala das "grass widows, spinsters of every kind, from the little girl in bib and tucker, to the full blown Anglo-Indian young lady" (295) $)^{85}$. No caso dos homens, menciona os "misanthropes and hermits", "civilians on the shelf, authors, linguists, oriental students, amateur divines", “worshippers of Bacchus”, “juniors”, "seniors” (295) Finalmente, termina a sua descrição da sociedade de Ootacamund fazendo, ironicamente, uma divisão em duas castas, a de Bombaim e a de Madras as quais, por sua vez, dividem-se em inúmeras subcastas: "But, unhappily, the said circle is divided into several segments, which do not willingly or neatly unite. [...] The Mulls [as the Madrassees are familiarly called] split into three main bodies, 1, the very serious; 2 , the petit-sérieux; and, 3, the unsanctified [...] Subdivision does not end here" (296) ${ }^{87}$.

Um outro aspecto importante do discurso de Burton, na sua construção do Outro Colonial, tem a ver com a reificação do Nativo transformado em objeto estereotipado. Segundo Menezes de Souza

\footnotetext{
83 'Eles mantêm as idéias, os preconceitos e as superstições do seu antigo estado'[...] Esta raça é, decididamente, a mais baixa na escala da humanidade civilizada que já se viu'.

84 'parecem seres superiores comparados com os degenerados Cristãos nativos.'

85 'viúvas e solteironas de todo tipo, desde as meninas bem vestidas até as maduras damas Anglo-Indianas'.

86 'Os misântropos e hermitões, civis aposentados, autores, lingüistas, estudantes do Orientalismo, amadores, adoradores de Baco, juniores e seniores.'

87 'Mas, infelizmente, o tal círculo está dividido entre vários segmentos, os quais não estão unidos. Os Mulls (como os de Madras são chamados) dividem-se em três grupos 1- os muito sérios; 2 os menos sérios; 3 os que não são santos. A subdivisão não termina aqui.'
} 
Em termos de representação do colonizado nas literaturas coloniais, esse processo de reificação consiste na negação da individualidade e da subjetividade do nativo, fazendo com que seja percebido por um sujeito colonizador como um objeto, um ser genérico que pode ser substituído, indiferentemente, por qualquer outro nativo (1996a:63).

Quando Burton visita Calicut, ele encontra-se com o Rajá, a quem apresenta como uma figura curiosa, ricamente fantasiada para a ocasião, que lembra ao leitor o tantas vezes textualizado tirano oriental: "Our Rajah was a little dark man, injudiciously attired in a magnificent coat of gold cloth, a strangely-shaped cup of the same material, and red silk tights" (178) ${ }^{88}$.

Da mesma maneira, Burton reifica o corpo feminino da mulher Nativa levando em conta seu valor erótico como objeto de desejo. Quando termina sua visita com o Rajá, Burton acidentalmente encontra as damas do palácio. A linguagem utilizada na descrição das princesas não só é altamente erotizada, como também altamente estetizada, ao ponto de assemelharem-se a representações pictóricas e literárias: “The ladies were very young and pretty - their long jetty tresses, small soft features, clear dark olive-coloured skins, and delicate limbs, reminded us exactly of the old prints and descriptions of the South Sea Islanders" (179) ${ }^{89}$.

Ao mesmo tempo, o valor atemporal e homogeneizante com o qual o colonizador designa o Nativo se reflete no texto de Burton pelo fato de mencionar que as roupas das princesas eram exatamente as mesmas descritas pelo "bom” Capitão Hamilton um século antes: "Their toilette, in all save the ornamental part of rings and necklaces, was decidedly scanty. It was the same described by old Capt. Hamilton..." (179) ${ }^{90}$.

\footnotetext{
88 'O nosso rajá era um homem pequeno e obscuro vestido numa magnífica jaqueta de tecido de ouro, um estranho boné do mesmo material e ajustadas calças de seda'.

89 'As mulheres eram muito novas e bonitas - seus compridos cabelos, suas delicadas feições, sua pele cor de oliva e seus delicados membros, lembravam as velhas pinturas e descrições dos Islanders do Mar do Sul'.

90 'A sua toilette em tudo, menos os anéis e colares, era escassa. Era a mesma descrita pelo Capitão Hamilton'.
} 
Todas as classificações de pessoas que Burton encontra em sua viagem seguem o mesmo padrão. Como no caso de Goa e Calicut, os "Hindus de Malabar", assim como os "Muçulmanos e outros Nativos de Malabar", e, finalmente, os habitantes dos Neilgherries, são apresentados em forma de catálogo, uma vez mais revelando como locus enunciativo, as narrativas de viagem do império inglês no século XIX.

Falando dos Hindus de Malabar - o verdadeiro "Outro"Oriental, segundo Inden - Burton apresenta as diferentes castas em termos quantitativos, desde os "Numboory Brahmanes" até "Christians and other strangers". Desta forma, embora o seu texto, como colocado anteriormente, não seja erudito, há um desejo de produzir um estudo sistemático sobre a essência indiana (caso isto fosse possível) como fica demonstrado no fato de Burton utilizar informação fornecida pelo censo realizado pela Coroa Britânica na sua contagem dos colonizados no ano de 1846. Uma vez mais, a textualização do Outro através de gráficos e números, é uma estrategia ficcional que, por um lado, mostra como o Outro é mensurado segundo uma conceptualização Ocidental e, por outro, visa a apagar diferências culturais que poderiam ser perturbadoras para a sua audiência inglesa.

No caso dos habitantes dos Neilgherries, eles são apresentados por Burton como pertencentes a um período anterior, um estágio mais remoto na escala da evolução humana, em termos de algumas das suas características físicas exemplificando as palavras de Mary L. Pratt quando salienta que "Conjunções particulares de pessoas, quando textualizadas, transformam-se na enumeração de seus traços" (1992:119). Porém, pelo fato de estarem em território da Índia-Inglesa e não serem uma séria ameaça para o seu império, Burton os textualiza de uma maneira muito menos antagónica - e com claras nuanças rousseaunianas - do que no caso dos nativos da Índia-Portuguesa ${ }^{91}$.

Dessa perspectiva, Burton afirma que enquanto "[t]here is nothing striking in the appearance of Numboory, [h]e is generally speaking, a short, spare man, of a

\footnotetext{
${ }^{91}$ Devemos essas reflexões a Alexandre Gebara - membro do curso ministrado pela Profa. Dra. Maria Helena Pereira Toledo Machado - cuja área de pesquisa para sua dissertasão de mestrado é, precisamente, a obra de Sir Richard Francis Burton.
} 
dark olive-coloured complexion, sharp features and delicated limbs" (214-215), no caso dos Nairs, eles são apresentados como "a fair and comely race, with neat features, clean limbs, and decidedly a high caste look" (221) .

Porém, no caso dos "Moplahs or Mapillahs - the Moslem inhabitants of Malabar", o autor enfatiza o fato deles serem mulatos: "[they] are a mixed breed, sprung from the promiscuous intercourse that took place between the first Arab settlers and the women of the country. Even to the present day they display in mind and body no small traces of their mongrel origin" (230-231) ${ }^{93}$. Da mesma maneira, em relação aos Mokawars das Neilgherries, Burton segue a classificação dos evolucionistas para quem, segundo Young, "as pessoas de pele escura, como os africanos, são alocados no último lugar da família humana, próximo do macaco" (1995:6). Assim, ele diz que" in appearance [they] are an uncommonly ill-favoured race; dark, with ugly features, and forms which a developist would pronounce to be little removed from the original orang-outang" (242) ${ }^{94}$.

Torna-se claro que, durante a sua viagem pela Índia, Burton nunca "goes native under the skin" (49) uma vez que sempre faz o leitor ciente de seu sentimento de superioridade outorgado pelo fato de ser um homem branco e europeu que considera os diferentes povos com que se confronta como versões inferiores quando comparados com o equivalente europeu. Na textualização de Goa and the Blue Mountains, então, o autor sempre se constrói marcado pelo que Marianna Torgovich chama de "a faculdade de individuação, distanciamento e julgamento essenciais para o ser europeu" (1996:49).

\footnotetext{
92 'Não há nada esquisito na aparência de um Numboory, ele é, falando em geral, baixo, magro, de pele cor de oliva, traços agudos e membros delicados.' No caso dos Nair eles são apresentados como 'uma raça clara e bem parecida com graciosos rasgos, membros leves e a aparência de uma casta alta'.

93 'Eles pertencem a uma raça híbrida, resultado da relação promíscua entre os primeiros colonos árabes e as mulheres do país. Ainda hoje, apresentam, em mente e corpo, marcas da sua origem mongrel'. 94 'Em aparência eles não são uma raça favorecida; escuros, de feios traços e formas que um evolucionista classificaria muito perto do orangotango'.
} 


\section{Conclusão}

Apesar de Burton tentar marcar uma diferença com outros relatos de viagem da época os quais, segundo ele, apresentam uma visão altamente estilizada do Oriente, achamos que também seu texto partilha das características do gênero, desde os aspectos retóricos até a sua maneira de textualizar o Outro e o seu mundo.

Dessa perspectiva, como assinalado anteriormente, na presente leitura de Goa and the Blue Mountains, consideramos aqueles aspectos retóricos, que ao dar uma determinada forma ao relato, revelam uma estrutura ideológica: a do colonizador na sua textualização do mundo colonizado. Na sua textualização do Oriente, Burton não oferece a seu leitor simplesmente prazer estético e informação, mas se coloca em uma posição de controle sobre o desconhecido, sobre o que é entendido pelo europeu como estranho ou exótico.

Assim, achamos que embora Burton fosse um agudo observador bem como profundo estudioso dos costumes, o seu olhar reflete a visão crítica do imperialista no Oriente, o que se manifesta na qualidade altamente irônica do seu relato em contraponto com o uso do pronome 'we' na sua intenção de despersonalizar a sua narrativa.

Ao mesmo tempo, no seu desejo de ser aceito pela sua audiência na Inglaterra, ele não só esconde sua conduta reprovável por meio de estratagemas literárias, mas também textualiza o que enxerga na Índia de uma maneira reconhecível e aceitável para a platéia 'back home'. Em um outro nível, isto vem demostrar que ele não tem se "amalgamado" com os Nativos mas, embora a cor da sua pele seja mais escura pela exposição ao sol da Índia, ele ainda pertence à Inglaterra e, portanto, conhece os seus códigos.

Todas essas considerações fazem com que o relato de Burton em particular e os relatos de viagem em geral, longe de ser narrativas inocentes, sejam consideradas como mais uma instância da maneira em que o colonizador tentava reconstruir e ordenar, a partir da sua própria perspectiva ocidental, aquele mundo longínquo e alheio através de um estilo que, ao apropriar-se do desconhecido, tentava controlar a alteridade com o propósito de reafirmar a superioridade da identidade ocidental. 


\section{Referências Bibliográficas}

BURTON, Richard F. [1851] Goa and the Blue Mountais or Six Months of Sick Leave. New Delhi \& Madras: Asian Educational Services, 1991.

DEVI, Vimala e M. DE SEABRA. A Literatura Indo-Portuguesa. Lisboa: Junta de Investigações de Ultramar, 1971.

HUTT, Anthony. Goa. A Traveller's Historical and Architectural Guide. Buckhurst Hill: Scorpion Publishing Ltd, 1988.

INDEN, Ronald. 'India in Asia: The Caste Society'. In Imagining India. Cambridge MA \& Oxford, UK: Blackwell, 1994. (49-74).

LODGE, David. The Art of Fiction. London, New York, Victoria, Ontario \& Auckland: Penguin Books, 1992.

MASCARENHAS-KEYES, Stella. 'Language and Diaspora: The Use of Portuguese, English and Konkani by Catholic Goan Women'. In Bilingual Women. Women and Second Language Use. Oxford: Berg Publishers, 1999. (149-166).

MENEZES DE SOUZA, Lynn M.T. 'De versões mutantes e lama no ventilador: a questão da história na literatura pós colonial'. In Cadernos de Estúdos Lingüísticos. Campinas. No. 30 Jan/Jun. (1996): 43-55.

'Re-membrando o corpo desmembrado: a representação do sujeito pós colonial na teoria'. Itinerários. Araraquara, No 9 (1996): 61-71.

' 'O fragmento quântico: identidade e alteridade no sujeito pós colonial'. Letras. Revista do Mestrado em Letras da UFSM (RS). Jan/Jun. 1997: 65-81.

PRATT, Mary L. [1992] Os Olhos do Império: Relatos de Viagem e Transculturação. SP/ Bauru: Edusc, 1999.

RICE, Edward. [1990]. Sir Richard Francis Burton. Trad. Denise Bottmann. São Paulo: Companhia das Letras, 1998.

SAID, Edward. [1978]. Orientalism. London, New York, Victoria, Toronto \& Auckland: Penguin Books, 1995.

Cultura e Imperialismo. [1993] Tradução: Denise Bottmann. São Paulo: Companhia das Letras, 1995.

SPURR, David. The Rhetoric of Empire. Durham \& London: Duke University Press, 1993.

SULERI, Sara. The Rhetoric of English India. Chicago \& London: The University of Chicago Press, 1992. 
TANNER, Tony. The Oxford Book of Sea Stories. Oxford \& New York: Oxford University Press, 1995.

TEIXEIRA, Ivan. Os Lusíadas. São Paulo: Ateliê Editorial, 1999.

TORGOVICH, Marianna. " What an Ecstasy It Would Have Been' Gide and Jung in Africa”. In Primitive Passions. Men, Women, and the Quest for Ecstasy. Chicago \& London: The University of Chicago Press, 1996. (23-41).

YOUNG, Robert. 'Hybridity and Diaspora'. In Colonial Desire. Hybridity in Theory, Culture and Race. London \& New York: Routledge, 1995. (1-28). 